\title{
Letter to the editor. Gene editing and disabled people: a response to Iñigo de Miguel Beriain
}

\author{
Felicity Boardman ${ }^{1}$ (D) \\ Received: 31 March 2020 / Accepted: 21 April 2020 / Published online: 30 April 2020 \\ (C) The Author(s) 2020
}

The response of disabled people to the possibility of human germline genome editing (HGGE) is an important topic, and one recently presented in an article by Kleiderman and Kellner Stedman (2020). The need to engage directly with members of the disability and rare disease community on such developments in genomic medicine was further underscored by my recent editorial (Boardman 2020), within which I highlighted the role of identity politics in informing reactions to HGGE amongst such groups who live directly with genetic conditions.

Writing in reaction to this editorial, Iñigo De Miguel Beriain (2020) has defended the use of HGGE against some of the critiques levelled by disability rights supporters that I outlined, by appealing to the principle of human dignity. He does this through the use of two key points:

1. That life without a disability should be regarded as preferable to one with a disability.

2. That if we were to accept that it is in the best interests of wider society to retain disability as a trait in its members, that 'forcing people to suffer' (De Miguel Beriain 2020) with disabilities to meet this end is unethical, because this would mean that the 'welfare of human beings [would] be sacrificed for the good of the collective', which, he argues, is not in keeping with the principle of human dignity.

I would like to respond to De Miguel Beriain's arguments by firstly highlighting the erroneous assumptions inherent in his first point, before showing how the second no longer stands once the first is refuted.

The argument that life without disability must surely be preferable to one with disability is not new, and one certainly

Felicity Boardman

Felicity.Boardman@warwick.ac.uk

1 Warwick Medical School, Gibbet Hill Road, Coventry CV4 7AL, UK that is largely upheld within the beliefs and reproductive practices of wider society. However, I dispute the claim, made directly by De Miguel Beriain, that the inferiority of life with disability to one without it is 'an acceptable conclusion for everyone' (De Miguel Beriain 2020).

There are numerous examples of people with genetic conditions who not only readily accept a child with the same condition as themselves (Henley 2016; Black 2016; Lancaster 2011) but also sometimes actively seek it (Teather 2002; Shanghavi 2006). A study by Baruch and colleagues, for example, found that $3 \%$ of the 137 IVF centres they surveyed in the USA had used PGD to actively select for the disabling trait of the parents (Baruch et al. 2008). For some would-be parents, there are practical considerations (e.g. linguistic, environmental) that inform a decision to select for disability, or, at least, refrain from preventing it (Shanghavi 2006). Yet for others, the decision stems from a fundamental conviction that life with a disabling condition is intrinsically of no less value than a life without it (Wallis 2019). As such, the physical, financial and psychological risks associated with technologically mediated reproduction are not justified.

In his response, De Miguel Beriain (2020) does acknowledge, however, that there are some disabled people who are reluctant to accept treatments for their condition, and as such may not welcome HGGE technologies. This group of people he refers to as 'type A patients', in contrast to 'type B patients', a category he reserves for those disabled people who would prefer removal of their condition. Sticking with this taxonomy, I accept De Miguel Beriain's statement that it is difficult - if not impossible-to prenatally predict which response (type A or type B) a would-be-disabled embryo will adopt to their condition. Experience of genetic disability is always mediated by social, cultural and environmental factors, healthcare availability and access, and psychological differences between individuals - factors that cannot be predetermined by a genetic test.

Despite this complexity, however, research is increasingly demonstrating that there are a range of factors that make a 
'type A' response to disablement more likely. Amongst which, early/congenital onset is a significant factor (Bogart 2014, 2019; Hahn and Belt 2004; Shakespeare 2006; Boardman et al. 2017; Jamoom et al. 2008). People who are born with their disability are more likely to have incorporated their condition into their identity and sense of self, and to have set their lives up around its existence than those who firstly experience able-bodiedness before becoming disabled. People with later onset disabilities typically undergo significant (and sometimes recurrent) identity negotiations and life re-structuring as they adapt to their disability, which may involve varying degrees of loss (Shakespeare 2006). It is these people who are much more likely to externalise their disability and separate it from their sense of self (Watson 2002). Such individuals are therefore more likely to view their condition as an unwelcome intrusion in their lives and to desire its eradication. These individuals are therefore far more likely to fall into the 'type B' category that De Miguel Beriain (2020) had in mind.

De Miguel Beriain (2020) has argued that it is these people - with experience of both being able-bodied and disabled - who can give us the greatest insight into the best interests of the would-be-disabled embryo in HGGE contexts. However, I suggest that we instead need to focus our attention on the experiences and perspectives of those whose conditions are early onset, many of whom (though clearly not all) will be 'type A patients'. As De Miguel Beriain himself points out, the single gene disorders that will most likely be targeted by HGGE are typically early onset in presentation; therefore, it is these people's lives who most realistically mirror those to be expected for the would-be-disabled embryos.

By highlighting this emerging body of research that demonstrates that there are factors that make a type A or type B response to genetic disability more likely, I am not suggesting that responses to disability can be predicted. Rather, we need to acknowledge the complexity of lived experience with genetic disability and the importance of not essentialising that experience as universally negative and always to be avoided. Indeed, as social model of disability theorists has long pointed out, there are a range of factors that have a significant impact on the experience of disablement that are entirely unrelated to the impairment itself (Barnes and Mercer 2004; Boardman et al. 2020).

We should be careful not to assume that disabled people who do not wish to use reprogenetic technologies in order to avoid disability, or who otherwise value their lives positively (perhaps by refusing therapies), are somehow misguided, or unrepresentative of the views of the wider population of disabled people. Indeed, research continues to highlight what has come to be termed the 'disability paradox', that is, that disabled people consistently rate their quality of life higher than others do around them (Albrecht and Devlieger 1999). At a time when disabled people are afforded greater support, access to healthcare and legal protections than ever before in history, the calculation of whether life with disability is inherently worse than one without cannot be treated as a one-off decision as it is so closely bound to the social and environmental context in which that life will be lived out.

De Miguel Beriain's second argument, that we should not inflict suffering (through disability) onto people for the greater good of society, is entirely defeated when we unshackle disability from its association with suffering. This is not to deny that genetic conditions can cause suffering - they can, and they invariably do. Moreover, as we have established, there is no sufficiently reliable way to distinguish between those who will suffer with their condition and those who will thrive. However, whilst De Miguel Beriain argues that, given this uncertainty, we should err on the side of editing genomes, we also need to take seriously the harms that are inflicted when we perpetuate and reinforce a presumed causal relationship between disability and suffering. This pairing not only impedes a thorough consideration of the range of human experiences that HGGE will impact, but also harms currently existing disabled people, in a variety of ways.

When De Miguel Beriain states that a person, or society, is unlikely to 'miss out on anything' by no longer having SMA or haemophilia, I would point to the testimonies of people who live with these conditions, and whose personalities and values (and those of the people around them) have been shaped, in various ways, by experiencing them (Boardman et al. 2017; Boardman and Hale 2018; Boardman et al. 2019) - even in cases where the condition was described as involving significant suffering (see 'Annette' (pp. 190-191) in Boardman 2017). Indeed, terms like 'Deaf gain' have emerged to describe the '...unique cognitive, creative, and cultural gains' that are brought about through Deaf ways of being in the world (Bauman and Murray 2014) and draw attention to the possibility of disability being an enriching experience, both at the individual and societal level.

It is my view that we firstly need to better understand what we mean by the term 'suffering' before we can presume to apply it to lives not yet lived. The accounts of genetically disabled people can help us delineate where the boundaries of suffering might lie, in order to better regulate the appropriate uses of technologies such as HGGE. Indeed, it is thoroughly in keeping with, and even integral to, the principle of human dignity to respect and uphold the value that people assign to their own lives - even if they contradict our own.

Open Access This article is licensed under a Creative Commons Attribution 4.0 International License, which permits use, sharing, adaptation, distribution and reproduction in any medium or format, as long as you give appropriate credit to the original author(s) and the source, provide a link to the Creative Commons licence, and indicate if changes were made. The images or other third party material in this article are included in the article's Creative Commons licence, unless indicated otherwise in a credit line to the material. If material is not included in the article's Creative Commons licence and your intended use is not permitted by 
statutory regulation or exceeds the permitted use, you will need to obtain permission directly from the copyright holder. To view a copy of this licence, visit http://creativecommons.org/licenses/by/4.0/.

\section{References}

Albrecht GL, Devlieger PJ (1999) The disability paradox: high quality of life against all odds. Soc Sci Med 48(8):977-988

Barnes C, Mercer G (eds) (2004) Implementing the social model of disability: theory and research. The Disability Press, Leeds

Baruch S, Kaufman D, Hudson KL (2008) Genetic testing of embryos: practices and perspectives of US in vitro fertilization clinics. Fertil Steril 89(5):1053-1058

Bauman H-DL, Murray JJ (eds) (2014) Deaf gain: raising the stakes for human diversity. University of Minnesota Press, Minneapolis

Black S (2016) Passing my disability on to my children, New York Times, September 7th https://www.nytimes.com/2016/09/07/ opinion/passing-my-disability-on-to-my-children.html. Accessed 29 April 2020

Boardman F (2017) Experience as knowledge: disability, distillation and (reprogenetic) decision-making. Soc Sci Med 191:186-193

Boardman F (2020) Human genome editing and the identity politics of genetic disability. J Community Genet 11:125-127. https://doi.org/ 10.1007/s12687-019-00437-4

Boardman F, Hale R (2018) How do genetically disabled adults view selective reproduction? Impairment, identity and genetic screening. Mol Genet Genomic Med 6(6):941-956

Boardman F, Young P, Griffiths F (2017) Impairment experiences, identity and attitudes towards genetic screening: the views of people with spinal muscular atrophy. J Genet Couns 27(1):69-84

Boardman F, Hale R, Gohel R, Young P (2019) Preventing lives affected by haemophilia: a mixed methods study of the views of haemophiliac adults and their families towards genetic screening. Mol Genet Genomic Med 7(5):e618. https://doi.org/10.1002/ mgg3.618

Boardman F, Clark C, Jungkurth E, Young P (2020) Social and cultural influences on screening programme acceptability: a mixed methods study of the views of adults, carriers and family members living with thalassaemia in the UK. J Genet Couns. https://doi.org/10.1002/ jgc4.1231

Bogart KR (2014) The role of disability self-concept in adaptation to congenital or acquired disability. Rehabil Psychol 59(1):107-115. https://doi.org/10.1037/a0035800
Bogart KR (2019) Socioemotional functioning with facial paralysis: is there a congenital or acquired advantage? Health Psychology. Advance online publication. https://doi.org/10.1037/hea0000838

De Miguel Beriain I (2020) Gene editing and disabled people a response to Felicity Boardman. J Community Genet

Hahn HD, Belt TL (2004) Disability identity and attitudes toward cure in a sample of disabled activists. J Health Soc Behav 45(4). https://doi. org/10.1177/002214650404500407

Henley A (2016) My 'disfiguring' condition is genetic - here's why I want a child anyway, The Establishment, September $8^{\text {th }}$, https:// medium.com/the-establishment/my-disfiguring-condition-isgenetic-here-s-why-i-want-a-child-anyway-e49a51b0ad30. Accessed 29 April 2020

Jamoom EW, Horner-Johnson W, Suzuki R, Andresen EM, Campbell VA, RRTC Expert Panel on Health Status Measurement (2008) Age at disability onset and self-reported health status. BMC Public Health 8(10). https://doi.org/10.1186/1471-2458-8-10

Kleiderman E, Kellner Stedman IN (2020) Human germline genome editing is illegal in Canada, but could it be desirable for some members of the rare disease community? J Community Genet 11:129 138. https://doi.org/10.1007/s12687-019-00430-x

Lancaster (2011) So what if my baby is born like me? BBC Radio 4, https://www.bbc.co.uk/programmes/b010n37y. Accessed 29 April 2020

Shakespeare T (2006) Disability rights and wrongs. London: Routledge

Shanghavi DM (2006) Wanting babies like themselves, some parents choose genetic defects, The New York Times, https://www. nytimes.com/2006/12/05/health/05essa.html. Accessed 24 Jan 2020)

Teather D (2002) Lesbian couple have deaf baby by choice, The Guardian, April 8th, https://www.theguardian.com/world/2002/apr/ 08/davidteather. Accessed 29 April 2020

Wallis JM (2019) Is it ever morally permissible to select for deafness in one's child? Med Healthc Philos 23:3-15. https://doi.org/10.1007/ s11019-019-09922-6

Watson N (2002) Well I know this is going to sound very strange to you, but I don't see myself as a disabled person: identity and disability. Disabil Soc 17(5):509-527

Publisher's note Springer Nature remains neutral with regard to jurisdictional claims in published maps and institutional affiliations. 